\title{
OBITUARY \\ A collection of memories of Professor Karl Lennert
}

Leukemia (2013) 27, 522; doi:10.1038/leu.2012.340

\section{Peter Banks}

Pathologist for Scientific Affairs, Ventana/Roche, Tucson, AZ, USA Clinical Professor of Pathology, University of North Carolina, Chapel Hill, NC, USA

Karl had a huge influence on my career and, indeed, on my life. I last visited him in Kiel 3 years ago. He was a man of great conviction who set a very high standard of scientific integrity and professionalism, and who exemplified this model in his every day life. He was always open to new ideas, and he enjoyed having visitors in his department, which came to be a busy hive of international pathologists. No one can duplicate his combination of achievements.

\section{Elias Campo}

President of the European Association of Haematopathology Professor of Pathology and Head, Hematopathology Unit, Hospital Clinic, University of Barcelona, Barcelona, Spain. E-mail: ECAMPO@clinic.ub.es

I came across the name of Professor Lennert when I was a medical student intrigued by the complex world of lymphocytes and their neoplasms. Tumors with obscure names started to have physiological and clinical meanings related to normal cell counterparts. When I started my residency program, my mentor in pathology Professor A Palacin, knowing my interest, gave me Professor Lennert's book 'Malignant Lymphomas Other Than Hodgkin's Disease'. The inspiring concepts and colors of that book generated a passion for understanding this field of pathology that molded my professional life. Blending morphology and immunology with their clinical impact opened the road to the current integrative perspective to study not only lymphoid neoplasms but also any type of tumors. In 1988, Professor Lennert founded the European Association for Haematopathology that celebrated the first joint meeting with the Society for Hematopathology in Barcelona in 1999. I had the privilege to organize that meeting and invite Professor Lennert, who attended with enthusiasm. Since then, all the meetings of these societies, organized each year on either side of the Ocean, have been considered joint meetings. This collaborative and collegial spirit to foster the knowledge and education on Hematopathology remains as a lingering and fruitful heritage.

\section{Elaine S Jaffe}

Head, Hematopathology Section, Laboratory of Pathology, National Cancer Institute, National Institutes of Health, Bethesda, MD, USA

Karl was a pivotal figure in shaping modern hematopathology. His vision was way ahead of its time, and he was the consummate observer and thought leader. We all are indebted to him for his scientific contributions and leadership.

\footnotetext{
Marsha C Kinney ${ }^{1}$ and Dr Robert D Collins ${ }^{2}$

${ }^{1}$ President of the Society for Hematopathology, Professor of Pathology, Director of Division of Hematopathology, The University of Texas Health Science Center at San Antonio, San Antonio, TX, USA
}

${ }^{2}$ Professor, Department of Pathology, Microbiology and Immunology, Vanderbilt University School of Medicine, Nashville, TN, USA

Upon hearing of Professor Lennert's death, Dr Collins called me to express his sadness and to say that Professor Lennert was a giant in hematopathology; he contributed more to our knowledge of lymphoma than anyone else.

I will always remember Professor Lennert's generous nature, his support for young pathologists and his strong, honest desire to understand the scientific basis of lymphoma. In 1986, he shared the BerH2 (now CD30) antibody with Dr Collins, giving the Vanderbilt group an opportunity very early on to study anaplastic large cell lymphoma (ALCL). Dr Collins sent all of us to Damp in September 1992 to attend the last Lennert tutorial, so that we could learn first hand from the man he respected so much. At the meeting, I mentioned our observations about the 'small cell variant of $A L C L$ '. Professor Lennert was sitting at the front of the room facing the audience and said 'I don't like that name' Two years later, he asked me for a reprint of my article and graciously told me 'You were right'. I was a very young hematopathologist at the time, and this meant so much to me that a man of Professor Lennert's stature would take the time to contact me and be so supportive of my work.

The Society for Hematopathology will truly miss Professor Lennert, our great friend, leader, scientist and mentor.

\section{Miguel Angel Piris}

Head, Department of Anatomic Pathology Hospital Universitario Marques de Valdecilla; and Scientific Director IFIMAV, Santander, Spain

I have always considered Professor Lennert as a reference in my career and in the field of lymphoma pathology. I appreciated particularly his willingness to be surrounded by bright people, and thus he created in Kiel the melting pot where, mixing science and diagnostic pathology, he recreated the German and European Pathology. As editor for his memories, I also appreciated his flexibility. Although he was considered by some of his peers as an inflexible person, he repeatedly demonstrated his disposition to negotiate and recognize the merits of his coworkers or the academic rivals. He liked particularly coming to Spain, for participating in meetings and also for having holidays. I had the opportunity of sharing good times with him in Madrid and Toledo, where he particularly enjoyed the 'tascas' where it is possible to enjoy popular 'tapas'. At that time I was just a young pathologist, but he always made me feel as a talented person.

\section{Steve H Swerdlow}

Professor of Pathology, Director, Division of Hematopathology, University of Pittsburgh School of Medicine, Pittsburgh, PA, USA

I wish to recognize what a very expert morphologist he was, for example, recognizing the special nature of what we now call mantle cell lymphoma, based on its fine morphological details, long before we were doing any of the myriad of ancillary studies used today to help make the diagnosis. He was a very confident pathologist, telling me once many years ago about the one mistake he made calling a T-cell lymphoma an immunocytoma because there were many associated plasma cells. He was also a very proper gentleman. 